\title{
Cytotoxicity of solutions recommended for the storage of avulsed teeth in cultures with periodontal ligament cells
}

\author{
Galia Cruz-Durán1, Raúl Ortiz-Daza Raúl', Jacinto Armando Díaz-Acevedo', Benjamín Sánchez-Trocino, \\ Ma. Concepción Arenas-Arrocena ${ }^{2}$ and René García-Contreras ${ }^{2}$ \\ ${ }^{1}$ Oral and Maxillofacial Surgery Area; ${ }^{2}$ Nanostructures and Biomaterials Area, National School of Higher Education, León Unit, Universidad Nacional
} Autónoma de México, León, Guanajuato, Mexico

\begin{abstract}
Introduction: The medium for avulsed teeth storage until their reimplantation is key to the preservation of human periodontal ligament fibroblasts (HPLF). Objective: Our purpose was to compare the cytotoxic effect of milk and isotonic solution, used for the storage of avulsed teeth, on the preservation of HPLF. Method: A subculture of periodontal ligament fibroblasts was carried out with a density of $1: 2\left(3 \times 10^{5} \mathrm{cell} / \mathrm{s} / \mathrm{mL}\right)$ and was incubated for 48 hours. The cells were divided in two groups, which were placed either in milk or isotonic solution for 24 hours at $5 \% \mathrm{CO}, 37^{\circ} \mathrm{C}$ and $95 \%$ humidity. The number of viable cells was determined with a colorimetric fast assay by the reduction of MTT and mitochondrial activity. Data were processed with the Shapiro-Wilk normality test, Student's t-test and paired Student's t-test (with significance set at 0.05). Results: The cells exposed to milk for 24 hours showed statistically significant cytotoxicity at concentrations of $0.09,0.39$, $0.78,1.56,3.125,6.25$ and $50 \%$. HPLFs exposed to isotonic solution showed no significant reduction in the number of cells at concentrations of 25 and $50 \%$. Conclusion: Isotonic solution appears to be better for HPLF 24-hour storage in comparison with whole milk.
\end{abstract}

KEY WORDS: Tooth avulsion. Tooth reimplantation. Culture medium. Isotonic solutions. Milk.

\section{Introduction}

According to the World Health Organization classification of dental trauma, dental avulsion is the complete displacement of a tooth from its socket in alveolar bone. ${ }^{1}$ An incidence of $16 \%$ has been reported among all permanent teeth dental traumas and 7 to $21 \%$ for deciduous teeth. Avulsion is a severe dental injury and its prognosis varies depending on the immediate procedure after the accident. Replanting the tooth in the corresponding place is one of the treatments of choice, even when carrying this out immediately is not always possible. ${ }^{2}$

Different studies concur that tooth replanting has a better prognosis the less time the tooth remains outside the alveolus and if the periodontal ligament is fully preserved. The prognosis considerably improves
(41\%) when the teeth still have an open apex, which increases the incidence for pulp revascularization. ${ }^{3}$ Periodontal ligament cells have constant blood supply, $\mathrm{pH}$ of $7.2,280$ to $300 \mathrm{mOsm}$ osmolality, so that when the tooth has been displaced from its alveolus, these cells start dying in less than 15 minutes, and in less than 1-2 hour, a sufficient number of periodontal ligament cells will have died, which drastically reduces replantation endurance and success. The result of ligament necrosis is observed with tooth radicular resorption and ankylosis in the long term.

Replantation survival depends on preserving the cells that compose the periodontal ligament unharmed. For this, it is crucial to maintain the tooth immerse in a fluid medium; milk, water or saliva have been reported to be optimal for preservation; storage in these fluids can increase the waiting time to up to 24 hours
Correspondence:

René García-Contreras

E-mail: dentist.garcia@gmail.com
Date of reception: 01-12-2016

Date of acceptance: 24-01-2018

DOI://dx.doi.org/10.24875/GMM.M18000133
Gac Med Mex. 2018;154:170-174

Contents available at PubMed www.gacetamedicademexico.com 
after avulsion, for subsequent manipulation and replantation. ${ }^{3,4}$ When the avulsed tooth is replanted after 15 minutes, periodontal ligament damaged cells cause partial resorption. Furthermore, replantation with a delay longer than 30 minutes can cause irreversible cell damage, replantation with a delay longer than $60 \mathrm{~min}$ utes in dry conditions can cause periodontal ligament (PL) necrosis, leading to extended root resorption. The best prognoses are obtained when extra-alveolar time does not exceed 5 minutes. ${ }^{5}$

The storage medium should be able to preserve cell vitality and adherence capacity, as well as to be readily available at the moment of avulsion. Both physiological osmolality and $\mathrm{pH}$ are crucial to preserve $\mathrm{PL}$ cells vitality. Cell growth occurs within a range of 230 to $400 \mathrm{mOsm}$; however, optimal growth ranges from 290 to $330 \mathrm{mOsm}$; $\mathrm{pH}$ ranges from 6.6 to 7.8 and the ideal range is 7.2 to $7.4 .^{6}$

Milk has been recommended as a medium to store an avulsed tooth because it has an osmolality (220 mOsm) that is compatible with that of periodontal ligament cells, in addition to being widely available; however it lacks the necessary metabolites and glucose for normal cell physiology. Milk keeps periodontal ligament cells alive for 1 to 3 hours. Cells that had been dried for 20 to 30 minutes and then placed in milk for 45 minutes have been shown to have much less vitality than those that were dried for only 10 minutes. $^{7}$ PL cells that were dried with air for 60 minutes and then placed in milk showed an almost inexistent vitality, which demonstrated milk capability to maintain osmotic pressure for PL cells, but showed no capability to reconstruct cell metabolism or to restore its vitality. Only cold milk can preserve PL cells capability to

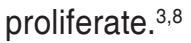

The isotonic solution used was a rehydrating, energizing commonly used isotonic beverage, which contains different components that might be able to preserve human periodontal ligament fibroblasts (HPLF): sodium chloride, potassium chloride, calcium chloride, magnesium chloride, sodium lactate and glucose; however, its $4.5 \mathrm{pH}$ might represent an important disadvantage in comparison with other solutions such as milk.

The purpose of this study was to compare the cytotoxic effect of milk and an isotonic solution, both recommended for avulsed teeth storage, in the preservation of HPLF, by means of cell-viability tests with a rapid colorimetric assay by MTT and mitochondrial activity reduction.

\section{Method}

\section{Primary cell culture}

The periodontal ligament cells (HPLF) were obtained by means of biopsy of the periodontal tissue from a procedure of caries or infection-free erupted third molars dental extraction in two 18 and 25-year old patients, after informed consent was signed and authorization was granted by the bioethics committee of the National School of Higher Education, Leon Unit, Universidad Nacional Autónoma de México León, Guanajuato, Mexico.

The extracted teeth with the obtained tissue were suspended in Alpha-MEM ${ }^{\circledR}$ medium (Life Technologies, Gibco, Carlsbad, Ca, USA), with $20 \%$ fetal bovine serum added (FBS, Life Technologies, Gibco, Carlsbad, Ca, USA), as well as $100,000 \mathrm{IU} / \mathrm{mL}$ of penicillin $\mathrm{G}$ and $100 \mu \mathrm{g} / \mathrm{mL}$ streptomycin sulfate ${ }^{\circledR}$ (Life Technologies, Gibco, Carlsbad, Ca, USA).

The tissues were sectioned into small portions with a number 15 scalpel blade. The explants were placed in $100-\mathrm{mm}$ culture boxes and incubated at $37^{\circ} \mathrm{C}$ with an atmosphere of $5 \% \mathrm{CO}_{2}$ for 2 weeks for exponential growth, with culture medium changes first at seventh day, and subsequently every other day. Cell growth was obtained as a primary culture with a population doubling level (PDL) of zero. When cellular density was $80 \%$, sub-cultures were carried out by detaching the cells from the culture plate with $1 \mathrm{~mL}$ of $0.25 \%$ trypsin- $0.025 \%$ EDTA-2Na $^{\circledR}$ (Life Technologies, Gibco, Carlsbad, $\mathrm{Ca}$, USA) in PBS(-) and incubating them for 5 minutes at $37^{\circ} \mathrm{C}$; detachment was verified by observing the culture box circulating cells under the microscope. The subcultures were carried out at a 1:3 concentration and the culture medium (DMEM $+10 \%$ FBS) was replaced every other day. Periodontal ligament fibroblasts have a lifespan of $30 \mathrm{PDL}$ in vitro (accumulated number).

\section{Cytotoxicity assay}

Subcultures were carried out at a density of 1:2 (3 $\times 10^{5}$ cells $/ \mathrm{mL}$ ) in 96-well plates (Ultra $\mathrm{Cruz}^{\circledR}$, Santa Cruz Biotechnology, Hamburg, Germany) and were incubated for 48 hours with $5 \% \mathrm{CO}_{2}$ at $37^{\circ} \mathrm{C}$ and $95 \%$ humidity. The entire culture medium was removed and the cells were placed in new, fresh culture medium. The whole milk (Pasteurizadora León, León, Guanajuato, Mexico) and the isotonic solution 
(Electrolit, Laboratorios Pisa, Guadalajara, Jalisco, Mexico) were inoculated at different concentrations, from 0 to $50 \%$. The cells were incubated for 24 hours at the same temperature and under the same conditions. Cell viability was determined with a rapid colorimetry assay by $\mathrm{MTT}^{\circledR}$ formazan reduction (Sigma-Aldrich, Toluca, Mexico).

Dissolved in $0.2 \mathrm{mg} / \mathrm{mL}$ of DMEM culture medium, the cells were incubated for 4 hours at $37^{\circ} \mathrm{C}$ and then the culture medium was removed until crystals were dissolved with dimethyl sulfoxide (DMOS, Karal, León, Mexico). Dose-response curve cell viability was determined and analyzed in a microplate spectrophotometer at $570 \mathrm{~nm}$. The assays were performed in duplicate, 16 for each solution.

\section{Statistical analysis}

Average, standard deviation, percentage and mean cytotoxicity concentration $\left(\mathrm{CC}_{50}\right)$ were calculated based on the dose-response curve. The data underwent Shapiro-Wilk, Student's t and paired Student's t normality tests. Statistical significance was set at $p<0.05$, with a reliability coefficient of $95 \%$.

\section{Results}

HPLF behavior was observed in both solutions, with cytotoxicity being assessed at different concentrations. The cells exposed to milk for 24 hours showed statistically significant cytotoxicity, with $p<0.01$ at $0.09 \%$, $0.39 \%, 0.78 \%, 1.56 \%, 3.125 \%, 6.25 \%$ and $50 \%$ concentrations, with $\mathrm{CC}_{50}=46.82 \%$ standing out.

The HPLF group exposed to the isotonic solution showed no significant differences, with $p>0.05$ at 50 $\%$ and $25 \%$ concentrations; however, these concentrations showed no cell-viability decrease below $80 \%$, showing cytostable effects on the culture. When compared, statistically significant differences were found for HLPF: at 12.5 and $25 \%$ concentrations, a $p$-value $<0.05$ was recorded, and in the rest, $p<0.01$ (Table 1 and Fig. 1).

\section{Discussion}

An ideal storage medium has been described to have to to possess biological properties to preserve cell vitality and adherence capacity, as well as to be available at the moment of avulsion. Both physiological osmolality and $\mathrm{pH}$ are crucial to preserve PL cells viability. Cell growth occurs within a range of 230 to
Table 1. Cell viability (\%) of the contact of an isotonic solution and of milk in human periodontal ligament fibroblasts (HPLF) cultures

\begin{tabular}{lccc}
\hline Dose (\%) & Isotonic solution (\%) & Milk (\%) & p (Student's t) \\
\hline 0 & 100 & 100 & \\
0.09 & $96.63 \pm 8.12$ & $87.41 \pm 13.7^{* *}$ & $<0.01$ \\
0.19 & $98.07 \pm 8.65$ & $96.37 \pm 10.03$ & $<0.01$ \\
0.39 & $99.09 \pm 6.32$ & $93.70 \pm 7.9^{* *}$ & $<0.01$ \\
0.78 & $94.85 \pm 17.14$ & $88.76 \pm 11.8^{* *}$ & $<0.01$ \\
1.56 & $99.85 \pm 6.86$ & $90.61 \pm 5.53^{\star *}$ & $<0.01$ \\
3.125 & $93.87 \pm 4.05$ & $89.21 \pm 4.18^{* *}$ & $<0.01$ \\
6.25 & $95.02 \pm 7.59$ & $85.91 \pm 4.41^{* *}$ & $<0.01$ \\
12.5 & $93.15 \pm 7.5$ & $96.20 \pm 11.72$ & $<0.05$ \\
25 & $89.68 \pm 7.21^{*}$ & $92.03 \pm 13.3$ & $<0.05$ \\
50 & $88.84 \pm 6.37^{*}$ & $43.9 \pm 12.7^{* *}$ & $<0.01$ \\
\hline
\end{tabular}

Differences between both solutions are expressed as the mean \pm standard deviation $(n=16)$. Columns represent different concentrations' paired t. ${ }^{*} p<0.05 ;{ }^{* *} p<0.01$.

$400 \mathrm{mOsm}$; however, it is optimal within a range of 290 to $330 \mathrm{mOsm}$; $\mathrm{pH}$ ranges from 6.6 to 7.8 , with the ideal range being 7.2 to $7.4 .^{2}$

Different solutions that might show favorable characteristics for HLPF storage have been investigated; those that have shown better capability for cell-viability preservation are Custodiol ${ }^{\circledR}$, a fluid for organ transportation, and Hank balanced saline solution (HBSS). ${ }^{9-}$ ${ }^{14}$ However, owing to their low availability and difficulty to find them, other solutions that might be good options for avulsed teeth storage have been investigated. According to Krasner et al., ${ }^{11}$ Sigalas et al..$^{13}$ and Özan, ${ }^{14}$ milk is an adequate solution for periodontal ligament fibroblasts (HPLF) storage owing to its osmolality and $\mathrm{pH}$, in addition to its ready availability in the place of injury. Other solutions have been tested ${ }^{14-18}$ such as Gatorade ${ }^{\circledR},{ }^{15}$ since its acidic $\mathrm{pH}$ showed high capability to produce cell apoptosis, and contact lens solution, ${ }^{14}$ which showed no significant differences with HBSS and milk; green tea extract ${ }^{16}$ which is efficacious to preserve periodontal ligament cell viability for 24 hours and that also showed anti-inflammatory, antioxidant and anticarcinogenic effects; coconut water demonstrated to be better for PL preservation in comparison with HBSS and milk. ${ }^{17}$

The used isotonic solution has a $\mathrm{pH}$ of 4.5 and osmolality of $116 \mathrm{mOsm}$. When the capacity to produce cytotoxicity at 24 hours at 0 to $50 \%$ concentrations was assessed, no significant difference was found in the reduction of cell viability. However, it is necessary 

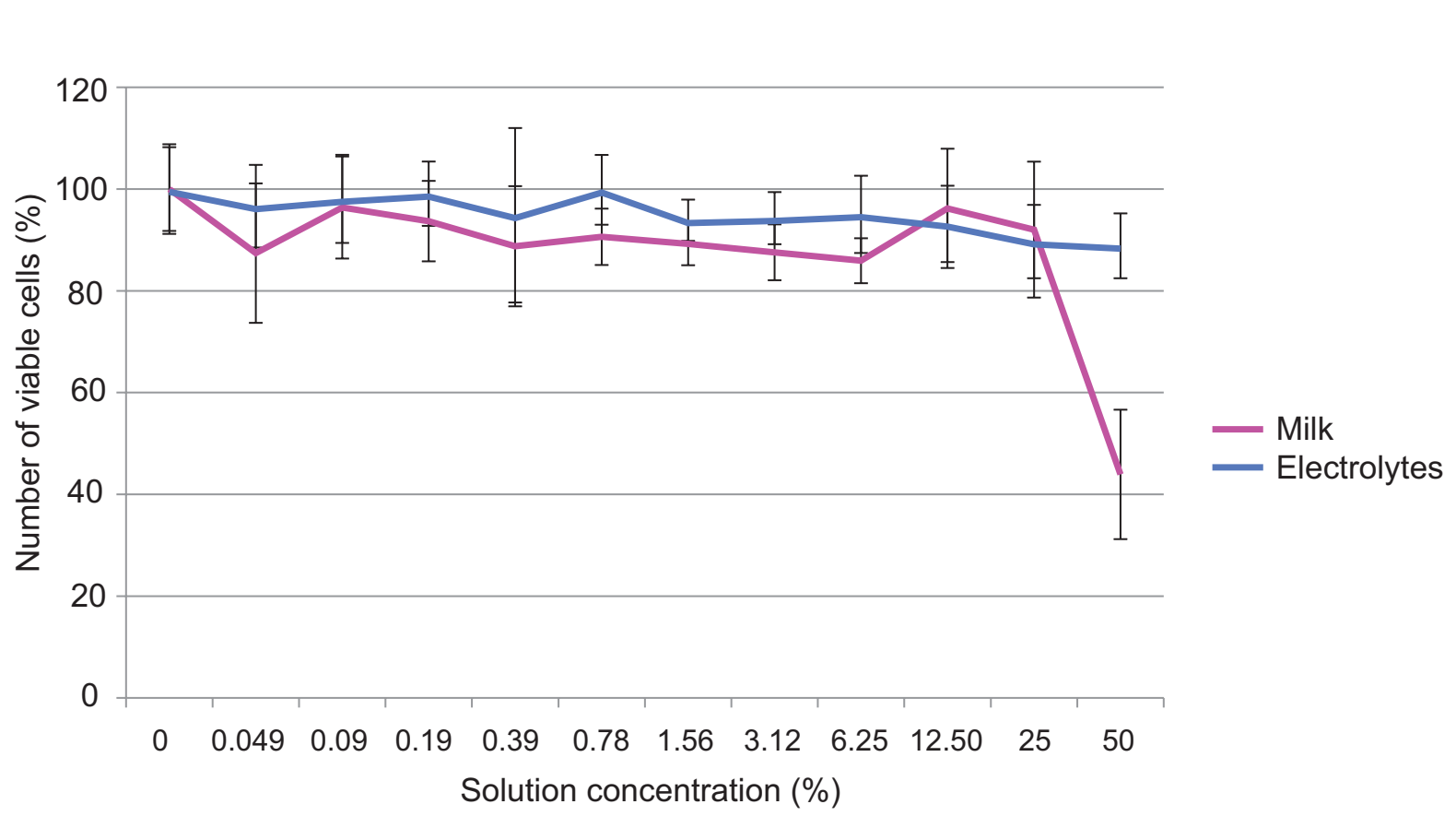

Figura 1. Efecto sobre la viabilidad de las células del ligamento periodontal, de la leche y la solución isotónica a diferentes concentraciones. Se puede observar mayor citotoxicidad de la leche a concentraciones mayores de $C_{50}$, con reducción de la viabilidad celular.

for other investigations to be carried out, since to this moment no other author has reported the potential application of this solution. As a reference, physiological saline has been tested, by means of which, according to Caglar, ${ }^{18}$ similar results to those of milk and HBSS were observed at 30 and 45 minutes.

In the present study, when the isotonic solution was compared with milk, the former was found to be significantly better in cell preservation at any concentration; significant differences were observed with regard to the control group only at $50 \%$ and $25 \%$ concentrations, probably owing to the electrolytes present in this solution, which are necessary for HPLF preservation; however, this is controversial, since its osmolality and $\mathrm{pH}$ are lower than those recommended in the literature. It is important pointing out that the isotonic solution is of low cost and is available in various stores and accessible to the entire population.

Since the results regarding milk and the isotonic solution are not consistent with those of previous investigations, or with those expected based on both solutions' biological characteristics, it is necessary for investigations aimed at testing the effects of both these fluids to be conducted with variability not only in concentrations but also in HPLF storage time before suffering irreversible cell death or expression of cytokines that may interfere in periodontal cell vitality, which is a fundamental aspect after dental avulsion.

\section{Conclusion}

Milk has been considered to be the ideal solution for the storage of avulsed teeth, owing to its biological characteristics and availability in the market. In this study, an isotonic solution that is highly available in Mexico was shown to apparently offer better results with regard to HPLF 24-hour storage.

\section{References}

1. Andreasen JO. Effect of extra-alveolar period and storage media upon periodontal and pulp healing after replantation of mature permanent incisors in monkeys. Int J Oral Surg. 1981;10(1):43-53.

2. Gopikrishna V, Baweja PS, Venkateshbabu N, Thomas T, Kandaswamy D. Comparison of coconut water, propolis, HBSS, and milk on PDL cell survival. J Endod. 2008;34(5):587-589.

3. Petrovic B, Marković D, Peric T, Blagojevic D. Factors related to treatment and outcomes of avulsed teeth. Dent Traumatol. 2010;26(1): 52-59.

4. Khademi AA, Saei S, Mohajeri MR, Mirkheshti N, Ghassami F, Alavi SA, et al. A new storage medium for an avulsed tooth. J Contemp Dent Pract. 2008;9(6):25-32.

5. Martin MP, Pileggi R. A quantitative analysis of Propolis: a promising new storage media following avulsion. Dent Traumatol. 2004;20(2): 85.89 .

6. Moreira-Neto JJ, Gondim JO, Raddi MSG, Pansani CA. Viability of human fibroblasts in coconut water as storage medium. Int Endod $\mathrm{J}$. 2009;42(9):827-830

7. Goswami M, Chaitra TR, Chaudhary S, Manuja N, Sinha A. Strategies for periodontal ligament cell viability: An overview. J Conserv Dent. 2011;14(3):215-220

8. Hiltz J, Trope M. Vitality of human lip fibroblasts in milk, Hanks balanced salt solution and Viaspan storage media. Endod Dent Traumatol. 1991;7(2):69-72.

9. Thomas T, Gopikrishna V, Kandaswamy D. Comparative evaluation of maintenance of cell viability of an experimental transport media "coconut water" with Hank's balanced salt solution and milk, for transportation of an avulsed tooth: an in vitro cell culture study. J Conserv Dent. 2008;11(1):22-29. 
10. Alaçam T, Görgül $\mathrm{G}$, Omürlü $\mathrm{H}, \mathrm{Can} \mathrm{M}$. Lactate dehydrogenase activity in periodontal ligament cells stored in different transport media. Oral Surg Oral Med Oral Pathol Oral Radiol Endod. 1996;82(3): 321-323.

11. Krasner $P$, Rankow $H$. New philosophy for the treatment of avulsed teeth Oral Surg Oral Med Oral Pathol Oral Radiol Endod. 1995;79(5): 616-623.

12. Poi WR, Salineiro SL, Miziara FV, Miziara EV. Education as a means of enhancing the prognosis of tooth replantation. Rev Assoc Paul Cir Dent 1999;53:474-479.

13. Sigalas E, Regan JD, Kramer PR, Witherspoon DE, Opperman LA. Survival of human periodontal ligament cells in media proposed for transport of avulsed teeth. Dent Traumatol. 2004;20(1):21-28.
14. Ozan F, Polat ZA, Er K, Ozan U, Değer O. Effect of propolis on survival of periodontal ligament cells: new storage media for avulsed teeth. J Endod. 2007;33(5):570-573

15. Chamorro MM, Regan JD, Opperman LA, Kramer PR. Effect of storage media on human periodontal ligament cell apoptosis. Dent Traumatol. 2008;24(1):11-16.

16. Hwang JY, Choi SC, Park JH, Kang SW. The use of green tea extract as a storage medium for the avulsed tooth. J Endod. 2011;37(7): 962-967.

17. Gopikrishna V, Thomas T, Kandaswamy D. A quantitative analysis of coconut water: a new storage media for avulsed teeth. Oral Surg Oral Med Oral Pathol Oral Radiol Endod. 2008;105(2):61-65.

18. Caglar E, Sandalli N, Kuscu OO, Durhan MA, Pisiriciler R, Caliskan EA, et al. Viability of fibroblasts in a novel probiotic storage media. Dent Traumatol. 2010;26(5):383-387. 